\title{
Who cares for what? Care networks and new urban activisms in Madrid: Restating solidarity
}

\author{
Andrés Walliser Martinez (jwallise@ucm.es) \\ Universidad Complutense de Madrid, Spain \\ François De Gasperi (francois.de-gasperi@ens-lyon.fr) \\ Université de Lyon, ENS de Lyon, France
}

The current COVID-19 pandemic has sparked a wave of mobilizations in Madrid that focus on providing care at the neighbourhood level. Since early March 2020, informal and horizontal care networks have provided food to thousands of people in several neighbourhoods of the Spanish capital on a weekly basis. In this paper we analyze the conceptualization of care in relation to the Spanish family-centred welfare state in a context of crisis while also examining how civil society provides care through social innovation and new forms of urban activism. We will look at how some aspects of care have reignited the commons in order to respond to a neoliberal city in crisis and assess the political emphasis on the 'City of Care' strategy developed by the previous New Municipalist local government between 2015 and 2019. In doing so, we determine the extent to which Care Networks and neighbourhood associations in Madrid are, from a social innovation point of view, the outcome of new municipalism policies. Finally, we analyze the role of participative local policies and community action in providing care during the current COVID-19 crisis.

Keywords: care, care networks, social innovation, New Municipalism, new urban activisms, commons

\section{Introduction}

In April 2020, the streets of Spanish cities were deserted; only shop-goers could briefly navigate the urban void. By late March, the news opened with an image, previously invisible despite the pandemic's spread. In Aluche, a working-class district in Madrid, long lines with hundreds of people, shopping gear in hand, waited patiently while keeping their distance from those around them. They were not queuing to access one of the local supermarkets. Instead, this heterogeneous contingent of neighbours of different ages, nationalities and professional backgrounds was waiting to receive their bag of basic food essentials from the Asociación de Vecinos de Aluche (AVA), one of the oldest neighbourhood associations in Madrid. A press article and a video by Santiago Serra, both titled Las Colas del Hambre ("The lines of Hunger") and presented as part of an artistic intervention, powerfully describes how many neighbourhoods in Madrid experienced the COVID-19 crisis (P1). Our analysis will turn its attention to this type of self-help network, or what we call care networks (CNs), born during the COVID-19 pandemic. 
Throughout this paper, we will analyze $\mathrm{CNs}$ and their role in caregiving at a micro local level in the context of the COVID-19 pandemic. After discussing the concept of care, its relations to the community and the institutions and the welfare policy realm that it interpellates, we will consider how COVID-19 poses specific challenges to social care in Spain. We will also narrate CNs' origins by analysing how care has been politicized in Madrid during the last decade. In order to do so we will focus on the 'City of Care' strategy launched by the New Municipalist local government in Madrid that was in power during 2015-2019. We will continue by assessing the resilience of $\mathrm{CNs}$ and urban social movements compared to existing public services in order to situate care in a context of crisis.

In the Spanish context, New Municipalism (NM) can be conceptualized as a set of local coalitions among left anti-austerity parties and social movements that ruled and, in many cases, continue to oversee city governments in Madrid (2015-2019), Barcelona, Valencia, Zaragoza or Cadiz in what Garcia (2017) calls "municipalist bids". In Spanish media, these cities have been referred to as the Ciudades del Cambio ("Cities for Change"). NM is a specific political approach to local government that goes beyond the traditional positions of municipalism. Municipalism traditionally has posed different approximations to city governance that emphasises a strong local economic, political or administrative autonomy (Monterde, 2019). NM goes beyond a strict claim for autonomy and expects different forms of power distribution and participation. In general, NM asks for radical democracy, including translocal and transnational solidarity. A New Municipalist perspective posits that institutions share power with citizens and social movements (Monterde, 2019, 58; Blanco, Subirats \& Gomá, 2018) and envisions urban solidarities as fundamental in the fight to contest neoliberal austerity urbanism and platform capitalism (Thompson, 2020). The focus on local government does not aim to simply transform it, but rather to use it as a strategic site for developing transformative and prefigurative politics (Russel, 2019).

We assume that care networks born during the pandemic are reconceptualising the very idea of care, taking it out of the private sphere where it has historically been confined. The politicization of care also reshapes the idea of a Spanish welfare state model, delineating a new path in which care can be carried out in and through the commons. We argue that this could serve as a possible counterbalance to contemporary trends that insist on the currently limited role of the local welfare state in the context of the neo-liberal city. The current context of care networks in Madrid seems to be an outcome of the cycles of mobilizations and associative culture that emerged in previous years and of the recent impact of the 'City of Care' political project put in place by NM. Other authors trace them back to neighbourhood-level grassroots dynamics and the new urban activisms that emerged in relation to the $15 \mathrm{M}$ movement and the 2009 economic crisis. In order to tackle this question of origin, we inquire into the structural and organizational roots of the CNs. Furthermore, the crisis raised by COVID-19 reveals the weaknesses of the welfare state and the capacity of civil society to redress those weaknesses through the reinforcement of social cohesion and solidarity. Therefore, we seek to assess whether crises are opportunities to reinforce and generate social cohesion through the activation of bottom-up mechanisms and alternative modes of urban governance. Overall, the paper contributes to a broader understanding of the invisibility of care as a political subject, its relegation to the domestic sphere, and the consequent challenge of imagining a model of 'care' based in the commons.

The article is rooted in an extensive revision of the literature on care, social innovation, new urban activisms and new municipalism and draws on primary resources, such as policy definition and program implementation documents, as well as analyses or summaries of their outcomes. We conducted eleven interviews between Winter 2020 and all 2020, while also actively participating in and carrying out participant observation of a specific local care network in Madrid. This research is based on a fieldwork carried out in Madrid, conducted for a 
master's thesis about the 'City of Care' program. In this initial state, six semi-structured interviews, covering the theoretical framing, policy design and implementation strategies deployed while implementing care-oriented local policies, were led with policymakers, local officials, and experts. A second phase of research was carried out in Madrid during the Fall of 2020. It included five semi-directive interviews with activists that oversaw coordination and organisational tasks in different care networks in Madrid, including the horizontal coordination structure overseeing networks and in neighbourhood associations from Aluche, a working-class borough with a high degree of mobilization and socially innovative actions. Promotional video recorded materials produced by the group coordinating care networks in Madrid have also been used. Some of the quotes come from seven edited videos for the fundraising festival in May 2020 with interviews recorded by the $\mathrm{CN}$ coordination group in an attempt to make their work and mission more visible (CM1). It is important to note that this article was being written (Fall-Winter 2020-21) while or soon after many of the events described took place. In addition, at present there is little available literature on care networks and the COVID-19 pandemic. As such, this article describes exploratory research on this phenomenon and seeks to open questions that will inform further research rather than provide closed conclusions. The same applies, to a lesser extent, to our analysis of the impact and outcomes of New Municipalist (from now on: NM) policies in the context analysed in this article.

\section{What is care about?}

\subsection{Understanding care}

Reflections on care originate from American philosophy and more precisely from feminist approaches to ethical matters (Gilligan, 1977). They oppose a "different voice" based on ethics, which would be mainly feminine (Gilligan, 1982), to the tradition of developmental psychology, which argued that people acquire moral aptitudes for as long as their cognitive capacities grow (Kohlberg, 1981). Instead of previously posing a rational principle to guide individual action, this voice takes into consideration the context in which a problem is formulated, uses emotions and feelings to solve it and by extension mobilises such emotions to address human vulnerability (Garrau \& Le Goff, 2010). Care recognizes vulnerability as what defines everyone's condition and identifies it as the source of fundamental human interdependence (Laugier, 2012). In this respect, the notion of care refers to the valorization and the preservation of a relationship that occurs in a situation of vulnerability thanks to a range of "feminine" qualities like empathy, or the ability to listen (Paperman \& Laugier, 2005). All in all, the aim of this approach is to redefine relations and boundaries between morality and ethics (Laugier, 2010). The ethics of care is a "for example" philosophy: resolutely contextual, it focuses on the close and the particular, the familiar and the ordinary; from a methodological point of view, it is an empirical, subjective and situated approach. Its claim is descriptive and narrative. It is opposed, in every respect, to morality, which is a 'that is' philosophical approach, an edifying and demonstrative philosophy that works from general principles and definitions with the aim of identifying rules of conduct and universally applicable laws; it is, in short, prescriptive, normative and authoritative (Brugère, 2017).

Abundantly discussed in the US in the nineteen-nineties (Noddings, 1984; Held, Kittay \& Meyers, 1987), the definition of "care" has widened to include the political (Tronto, 1993). More than just a female attitude or moral disposition, care has been reconsidered as the articulation of this specific voice or point of view with concrete activities that concern the whole world. In specific terms, care encompasses all the activities related to the management and daily maintenance of people's lives, health, and well-being (Comas d'Argemir, 2016). And in its broadest sense, care is defined as "a species activity that includes everything that we do to maintain, continue and repair our 'world', so that we can live in it as well as possible. That 
world includes our bodies, ourselves, and our environment, all of which we seek to interweave in a complex, life-sustaining web" (Fischer \& Tronto, 1991, 40). This definition of care includes two dimensions: a 'material' one that consists in the accomplishment of concrete tasks with tangible results (shopping, cleaning, healing, and more widely all the activities that are linked to taking care of the body) and an 'immaterial' one, that is more effective and relationally related to emotional well-being (Perez Orozco, 2014).

While care is crucial for "social reproduction" (Harris \& Young, 1981), it is still undervalued as a task and associated with a gender stereotype in a world that increasingly values production (Comas d'Argemir, 2016). This is because care has always taken place within the private sphere and has been carried out mostly by women and without monetary remuneration. In this sense, care is also linked to a historical process that eventually confined feelings and women at home, thus paving the way to a domestic localization of care activities (Tronto, 1993). As such, here our aim is to oppose a political definition of care that goes beyond the shadow of domestic space and recognizes care as an essential responsibility, task and quality in everyday life.

\subsection{The crisis of care}

Recently, the discredit of care has led to what some authors call the 'crisis of care' in Western countries (Hochschild, 1995). This crisis evokes a joint movement of insecurity for caregivers and a threat to the quality of care itself. First of all, due to the 'aging of the aging' (Comas d'Argemir, 2016), care necessities are growing dramatically in Western countries where dependency situations linked to old age, chronic diseases and disabilities are growing. This results in the emergence of important needs for long-term care that undoubtedly will increase exponentially in the coming years. Meanwhile, providing care grows more complicated because of the progressive dismantling of the welfare state and the breakdown of community and family ties caused by the gradual privatization of care. Thus, care activities have been merchandized and are mostly carried out by poorly paid immigrant women, who are now key actors in "international care chains" (Pautassi \& Zibbechi, 2013). While some middle- and upper-class households can outsource care responsibilities thanks to the market, poor ones, which often include caregivers themselves, are no more able to care for themselves and their relatives. Although this phenomenon is long-standing, the volume of people now involved in care-related migration is unprecedented (Ehrenreich \& Hochschild, 2003; Perez Orozco, 2006).

\subsection{Towards a social care analysis}

Care is a key concept in political science that is used to assess the contemporary evolution of social policies provided via the welfare state which is also referred to as "social care" (Daly \& Lewis, 2000). This notion is used to depict how societies organize the labour of care between the different agents that carry it out. These agents include the family, the state, the market, and the non-profit sector, which are all central elements in what some authors call the "care diamond" model (Razavi, 2007; Rodriguez Enriquez, 2015). More specifically, social care relates to the "activities and relations involved in meeting the physical and emotional requirements of dependent adults and children, and the normative, economic and social frameworks within which these are assigned and carried out" (Daly \& Lewis, 2000, 5). At a macro level, it underlines the division of care labour, as well as the responsibility and costs between the four corners of this care-diamond. At a micro level, it enlightens the distribution of care (labour, cost, and responsibility) among individuals within the family and community and, by extension, the kind of state support available to care beneficiaries and caregivers. Social care is a helpful tool for examining the nature and limits of welfare state benefits and how they vary over time and across national boundaries. This tradition has strengthened care as an academic 
concept and made it possible to convert it into a political category (Borderias, Torns \& Bengoa 2018).

\subsection{The value of a social innovation approach to understanding a model of care based in the commons}

Social innovation is also a useful concept to explain a community bottom-up approach to care, which in our analysis is epitomized in CNs. Social innovation refers to the satisfaction of specific needs through collective initiatives (Chambon et al., 1982). These initiatives are not necessarily the work of public institutions, which can both constrain or contribute to social innovation (Gonzalez et al., 2010). Different authors have argued that economic crises are catalysts that provoke and accelerate social innovation in a context where vulnerable sectors of society face worsening conditions (Blanco \& Leon, 2017). For the purposes of our analysis, we will refer to a general definition of social innovation as, "the satisfaction of basic needs and changes in social relations within empowering social processes (Moulaert et al., 2010, 27).

Moulaert's (ibid.) 'spatial' conception of the community gives prominence to the role of neighbourhoods. Understood as places of life experience and everyday practices, neighbourhoods are where mobilizations and action against social exclusion and austerity urbanism are initiated and staged and where new political rights are defined. These practices are often embedded in neighbourhoods as strategies developed by and for deprived groups that are outside or at the limits of the welfare realm. The spatial dimension of social innovation in relation to care networks is relevant to how neighbourhoods organize, their resilience in times of crises and uncertainty, the density of their networks and their reach in terms of resource mobilization, including the number of volunteers and activists involved, the quantity of formal and informal associations and groups linked to it or the number of households benefited or supported. We will analyze this in more detail below.

In this context, social innovation appears as a lever for redefining the balance of power by deepening bottom-up logics of governance. These initiatives occur at a distance from the public administration, often depending on the degree of tolerance and acceptance of local institutions in relation to the political options provided by those in office. Hence, governance patterns can be reshaped at neighbourhood, district, and city levels by opening up new spaces of negotiation and autonomy. Somehow these initiatives can also lead to the emancipation of previous subordinations to institutions in the context of neoliberal urbanism, which often neglects or directly confronts the role of grassroots organizing within social and cultural urban dynamics (Blanco et al., 2018)

In our analysis, the social innovation dimension of care networks is linked to the resilience of vulnerable communities in deprived neighbourhoods but also to their capacity, their modes of operation to very dynamic and unpredictable contexts, like that created by the COVID-19 pandemic. In order to accurately describe these networks, we will focus our attention on these dimensions of social innovation, which are essentially interconnected: the need to satisfy basic human needs; the empowerment of originally marginalized groups and communities; the redefinition of social and power relations within and between collectives; and a more general governance of power (Moulaert et al., 2010, 199).

We will now assess the provision of care in Spain in comparison to national contexts and describe the Spanish welfare state model. We will also narrate the origins of CNs by turning our attention to the recent history of the politicization of care in Madrid in order to better understand the role of care networks in the context of COVID-19. Finally, we will discuss their possible relation to Spanish social care dynamics. 


\section{How does Spain care? Nuevo Municipalismo and the 'City of Care'}

\subsection{What are care arrangements in Spain?}

Like other countries in Southern Europe, that originally had 'residual' welfare states (Titmuss, 1987), Spain's urbanization and economic growth, followed by new public management logics introduced subsequently, have resulted in a 'privatization of caring' that still does not automatically eliminate family members as caregivers (Motel-Klingebiel et al., 2005). Among this large and diverse group of countries, the key variation however "centres on the nature of 'privatization"' (Daly \& Lewis, 2000, 9). In Spain, care activities traditionally are the responsibility of the family, contributing to what is called "a family-centred model of care". Familycentred welfare states in Mediterranean countries are a combination of the three main welfare models defined by Esping-Andersen (1990): the Scandinavian universalist; the AngloSaxon means-tested model where benefits are only available under certain income thresholds; and finally, the Conservative-Corporatist welfare state, linked mainly to workers' relations with the labour market. Spain, Portugal, Italy and Greece share common needs and lifestyles and also embrace a 'welfare mix' model that rests on family micro-solidarity and a combination of universalist and means-tested models (Moreno, 2001).

This trend has the double 'advantage' of not questioning the traditional family-centred model, nor the supposedly 'natural' inclination of women to assume caregiving responsibilities. Above all, confining care activities within the home tends to make these tasks an individual problem to be solved within the private sphere, which runs counter to the political definition of care. Households are therefore subordinated to different strategies that imply both material and immaterial transfers (ibid., 73).

Most recent data available regarding social care dynamics in Spain show that 33.7 per cent households require care, of which 10.8 per cent are considered to require long term care. In 88.1 per cent of cases, care takes place at home, and in 64.1 per cent it is provided by women (CIS 3009/2014, in Martinez Bujan, 2019). The same applies for childcare during the first three years, in which 80 per cent of responsibilities are assumed by females (mothers, grandmothers or caretakers), and 73.5 per cent of the whole childcare range age (Meil et al., 2018). A substantial part of these immaterial transfers, especially those related to caregiving, still relies mainly on the feminine component of households. This family-centred welfare culture also relates location strategies taken by new households in order to maintain family bonds by choosing housing options that are close to the main family household (Sorando \& Leal, 2019). The financialization of urban real estate markets resulting in steep housing price increases, even in the most deprived neighbourhoods, tends to disrupt these dynamics, thus having a severe impact on the care cycle within the family-centred welfare model (Walliser \& Uceda, 2020).

The recent reorganization of welfare also implies change for care recipients. The application of market principles to public sector services results in the systematic targeting of those in need of services, which in turn means that others no longer qualify for assistance and are somehow crowded-out of the system. This tendency is not neutral and reconfigures the nature of care itself, which is furnished by the state, leading to the specialization care offers which eventually focus solely on long-term care. Symmetrically, as the scope of service definitions are reduced, a problem arises for all those who are no longer characterized as dependent or vulnerable (Daly \& Lewis, 2000). This difficult frontier regarding the scope of care to be provided by the state finally leaves vacant an enormous space reserved for day-to-day care. CNs quickly fill this void, and it is this phenomenon that is of particular interest to us here. 


\subsection{The $\mathbf{2 0 0 8}$ crisis as a rediscovery of the community as a care agent}

The 2008 financial crisis greatly affected the Spanish economy and has called its social care model into question. Sparking a serious employment crisis, the financial downturn provoked the adoption of a series of austerity measures in a policy response that sought to draw back the State and reinforce market mechanisms within the field of public policy management (Peck, 2012). While the unemployment rate peaked at 26 per cent of the Spanish population in 2013 (and later reached 17 per cent in 2017) (INE, 2020), the precariousness in labour skyrocketed to 40 per cent. In the meantime, austerity has contributed to putting pressure on and overloading assistance and care responsibilities on families and women (Deusdad et al., 2016). At the same time, some key policies targeting welfare development were reduced or their slow implementation drew out large contingents of beneficiaries: both caretakers and caregivers such as the Law on Dependence and the Law on the Promotion and Autonomy of Dependent Persons (IS1). The viability of others was jeopardized, especially those associated with the social risks that arise from the very context of vulnerability linked to the destruction and precariousness of employment (Martinez Bujan, 2019).

By 2009 , crisis austerity governance began to specifically affect local urban policy and welfare provision, which had already been successfully privatized and externalized during the previous two decades. New public management initiatives and the convergence of conservative neoliberal governments in the city and region of Madrid during that period (Janoschka \& Mota, 2020) developed a growth machine with massive investment in infrastructures and other that peaked in 2013 a debt of 8 billion Euros, or 154 per cent of the city of Madrid's annual budget. After 2009, strict fiscal supervision passed by Parliament limited the capacity to invest in new facilities, subsidies, anti-poverty programs and in human resources (P2). Only existing expenditures were allowed into the yearly budget such as investment in already existing facilities, rather than in services and the provision of labour. By 2016, NM governments such as Madrid and Barcelona contended to the state regulation that define the 'expenditure ceiling' (techo de gasto), that was considered as a political restriction to hinder the development of their political program (P3).

Despite all this, the fragile economic and political context in Spain has been propitious for the rediscovery of one corner of the 'care-diamond' model that had been obviated by politicians, as it had received little attention from the social sciences (Martinez-Bujan, 2019). Authors who question the optimal management of public resources have shed light on the idea of 'the commons' as an important axis of reflection in this context (Laval \& Dardot, 2014). Notions like 'welfare of the commons' (Vercellone, 2015) or 'commonfare' (Fumagalli \& Lucarelli, 2015) considered the idea of the commons and community as a way to compensate for the state's shortcomings in providing care and more broadly as a way to invent sustainable welfare systems capable of meeting people's needs through collaborative formulas that encourage participation tools and solidarity care practices among citizens.

In the case of Mediterranean family-centred models, this approach could serve as a 'fourth way' between itself and the three European Welfare State models, assuming that the Mediterranean model is included in the Conservative-Corporatist one as Esping-Andersen (1990) suggested. Although care in the commons does not substitute the welfare state as a whole, it can contribute to strengthening community relations, politicizing care and providing a realm of activities, often petty actions in terms of welfare provision but certainly relevant to supporting vulnerable residents' quality of life from a material, emotional and social point of view.

\subsection{New urban activisms: actors of care in the commons}

In Spain, this resurgence of the community has been a by-product of citizens' growing distrust in politicians and expanding criticism of corruption scandals that emerged in the early 2010s (Castells, 2019). Since the retrenchment of public spending and growth of labour precarity, 
socially innovative forms of collective organization have emerged and gained strength in Spain (Blanco et al., 2016). Care, undoubtedly, was influenced and informed by the growth of such collective organization. Some of these emerged during the 'Indignados' 15-M movement, a non-violent prefigurative social movement born in Madrid main plaza, the Puerta del Sol in Madrid on May 15, 2011. This citizen movement used various forms of action (like the occupation of squares and street marches) to protest against Spain's political elites. Beyond a criticism of corruption, the 15-M Movement demanded the end of the two-party political system and made claims for "Real democracy, now", that is to say, the invention of new ways of conducting politics that would be more representative and participatory. Other initiatives were boosted by the collaborative dynamism produced by new mobilizations and social innovation dynamics, such as 'new urban activisms' (NUAs) (Walliser, 2013; Medina-Garcia et al., 2021) and traditional neighbourhood associative movements (Asociaciones de Vecinos).

After the 15-M movement, the process of consolidating NM activated a conglomerate of social movements, grassroots organizations and informal groups, social innovation that have been instrumental to a range of issues crucial to confronting neoliberal urbanism, thus ushering in an informal process of collaborative 'theory building' beyond the strictly local realm (Russel, 2019, 3).

As a senior officer from the local public health department stated about the case of Madrid:

"May 15th, 2011 was a turning point in which a citizen rebellion, or indignation about the forms of institutionalism that had been in place until then, became visible... and in some ways a series of philosophical or utopian currents that had to do with rethinking the city, for example, became visible, didn't they? So, as I was saying before, it ranged from ecofeminism to issues that had to do with the social and solidarity economy." (Interview-FP1-2020)

Although the members of these urban social movements have been extensively researched (Tejerina \& Perugorria, 2017), we approach them as part of NUAs, that is as crucial actors in the reinvention of Spanish urban policies throughout the last decade (Walliser, ibid.; Walliser \& De la Fuente, 2018). NUAs are urban social movements with specific organizational structures, repertoires of action and participants. Summing up their main characteristics, it can be said that they have: 1 ) loose organizational structures; 2 ) blurred lines of distinction between political action, mobilization and professional practice; 3 ) the use social innovation and ICT technology to collect and expand collective intelligence in open source formats, to build identity and also to mobilise on- and offline; 4) heterogeneous social and political compositions; and finally 5) a capacity to promote, network and function through bottom-up autonomous actions. In the Spanish case, they initially did not have formal links to, nor did they identify with, official political organizations. However, they later fed political coalitions that came to power with the emergence of NM. Most of NUAs' features can be identified in the aforementioned care networks in Madrid, all of which emphasise autonomy and self-organization as we will explain in more detail below.

\subsection{The 'City of Care' experience, a prelude to care networks?}

NUAs finally found a political outlet in the Spanish municipal elections celebrated in 2015. Citizen lists from NM groups from various persuasions (eco-feminism, the right to the city, social and solidarity economy, or neighbour associations, among others) and affiliated or not with new and old left-wing parties such as Podemos or Izquierda Unida won elections in several key Spanish cities, among them Madrid, Barcelona and Valencia. These elected governments soon formed what would later be described as Ciudades del Cambio ('Cities for Change') (CM2). New elected officials, nourished by the municipalist leanings of new political actors from political activist circles, introduced the concept of "care" in the municipal policies they 
put forth. They attempted to use it as a transversal political concept, reinforced their insistence on participation and devolution as new modes of waging policies. In this process, Madrid became a key point of reference for this concept in Europe. With support from City Hall and leadership from the Health department, Madrid launched the 'City of Care' Project (e.g., 'La ciudad de los cuidados'), which sought to recognize care holistically, thus recognizing everything that contributes to the support and maintenance of human life. The plan was designed around 4 axes whereby care could be integrated into: (1) the context of public space design and community life; (2) administrative responsibilities and activities; (3) daily life; and (4) systems of production (Ruiz et al., 2018). It was an ambitious plan that traversed multiple governmental Departments and sought to implement pilot projects and prototypes to be tested and improved at the neighbourhood level and from a community perspective. The reflections regarding the objectives of this 'City of Care' strategy made by the previously cited interviewee are significant:

"We wanted projects that were community-based and that were cross-cutting in the sense that they covered different areas of knowledge, and that were hybrid. Hybrids in the sense of articulating the administration with the social initiatives that existed in those territories." (Interview-FP1-2020)

In relation to the outcomes of a model of care in the commons, an expert involved in the 'City of Care' project declares that the goal was to:

"Consider that the public administration should undoubtedly provide a series of services, but the administration will not be able to reach everything. So, what we also want to facilitate is the ability to value the communities themselves, to enable the strengthening of these communities so that they themselves can organize and structure themselves to face the risks of their daily life, their daily difficulties, because we believe that the state has to provide this or help solve these issues, but another function that the public administration must also be to establish the bases or structures that allow communities to organize themselves." (Interview-FP2-2020).

The 'City of care' initiative reflected the articulation of more horizontal public action through governance patterns that instituted new forms of cooperation between public authorities and citizens. Hybridization, resulting from the public-social partnership (Ayuntamiento de Madrid, 2018), thus appears to be, above all, an innovative tool for integrating citizens into the process of making public policies.

In short, the 'City of care' was part of a recent trend in which care is politicized and socialized through an alliance between public institutions, particularly municipal ones in southern Europe, and organizations that could make up for the public systems' deficiencies or even propose an expansion of its services (Solis, Bujan \& Paredes Chauca, 2018). In some aspects of welfare and community building, the social-public partnership could substitute the public-private partnership introduced by the new public management trends that emerged in Spain after the 2000s (Ayuntamiento de Madrid, 2017). This new logic was often approached from an experimental point of view, taking the form of prototypes or pilot programs focused on testing and fine-tuning project efficiency and viability including the lease of public facilities to develop self-managed community initiatives (Atlas del Cambio, 2018).

As a policy pillar positioned to define the city's model, the 'City of Care' ended up being more of a strategy than a grand policy position. Despite the creation of a specific task force dedicated to wage this policy, the lack of transversal budgeting and inter-departmental coordination (both at political and officer level) together with internal political tensions and austerity expenditure limitations, largely limited its capacity to implement scarce, but relevant projects. This also paved, as stated by several interviewees (FP1, FP2) the way to signing of external 
contracts that generated tensions with the government, unions and right-wing opposition. In light of the current neoliberal government's systematic demolition of governance and regulatory efforts or the NM's attempts to introduce social and institutional innovation through a 'City of Care' policy, this topic deserves further research in the future. As seen in the previous two decades in Madrid, the neoliberal city is openly hostile to progressive urban movements, but this hostility also enables them to articulate and mobilise under the right to the city umbrella (Mayer, 2009).

Socially innovative initiatives, therefore, lie precisely at the interstices of a kind of public action that recognizes its inability to be omnipotent. Let us now go into the details of our case study in order to identify how these networks are positioned, as well as their nature, origin and destiny.

\section{Care networks in COVID-19's neoliberal city}

\subsection{The COVID-19 pandemics: A social innovation catalyst}

During the current pandemic, the economic situation facing thousands of families in Spanish cities rapidly became critical. The extremely strict first wave of confinement measures put in place between early March and May 2020 led to an unprecedented economic and social crisis. The closure of businesses and the reduction of the labour market resulted in a shrinkage of the workforce and the further precarization of the working conditions of millions of already precarious workers despite financial support measures provided by the government. The coronavirus pandemic forced the Spanish government to take a series of economic measures aimed at tackling a health crisis that left more than 38,000 dead by early fall 2020 and 61,000 dead by January 31st, 2021 (RTVE, 2021). The government has passed several decrees that address the economic impact by providing aid to the unemployed, support to economic sectors and loans for the self-employed and SME. In addition, rent subsidies, eviction moratoriums and the automatic renewal of rental contracts until January 31st, 2021, and a 25 per cent discount on electricity bills for vulnerable groups or individuals. Regarding employment, companies were barred from firing anyone during a six-month period, and the Government committed to compensate the salaries paid by those businesses that claimed reduced or inexistent activity (also referred to as an ERTE). Finally, the government established a Minimum Vital Income for households whose income has been drastically reduced by the coronavirus and provided support for self-employed workers (Plataforma Tercer Sector, 2020; Gobierno de España, 2021)

A forced transition to alternative forms of work and the transformation of whole productive sectors have led thousands of families to live in critical social and economic conditions marked by strong socio-spatial components. Deprivation and poverty are predominantly affecting working class neighbourhoods where several vulnerable groups meet: senior, often singleperson, households; local working-class families and migrant families who have difficulty accessing decent housing conditions. It is also important to note that Madrid is dramatically polarized along lines that segregate the South (deprived populations) from the North (mainly affluent ones, although sometimes with exception) (Sorando \& Leal, 2019).

Another source of impoverishment is the precarious labour market and new labour market opportunities that generate highly flexible, yet vulnerable jobs, such as new platform capitalism businesses like food delivery that is widely available to young people such as the new platform capitalism businesses (Srnicek, 2016). The impact of globalization on urban systems in Spain has a territorial dimension which affects precarization, dispossession and unemployment in Madrid and its metropolitan area (Mendez, 2017).

In Madrid, the sudden rise of COVID-19 infections in early March changed the life of the city within days, thus provoking the gradual activation of mutual aid networks, some of which 
existed previously while new ones took form, at the neighbourhood level (Herrera-Pineda \& Ibanez-Gijon, 2016). We will call these networks care networks (CNs), or redes de cuidados in Spanish. In the following sections we are going to describe the nature, structure and context of $\mathrm{CNs}$, the evolution of their aims and actions, their relation to institutions and their socially innovative role in providing care to the community.

\subsection{Care networks focus not only on what is done but also how it is achieved}

CNs in Madrid are horizontal non-hierarchical organizations with highly heterogeneous structures in which different kinds of associations, action groups and individuals join to provide care and solidarity to their members and other residents in a given area. They share claims regarding rights to the city and often demand investment in social infrastructure (Domaradzka, 2018), participation in decision-making, the autonomous self-management of spaces (Hamel, 2014, 466) and a prefigurative political orientation towards urban justice, all of which are seen as tools for 'the deliberate experimental implementation of desired future social relations and practices in the here-and-now' (Raekstad \& Gradin, 2020, 22). The manifestos (CM3, CM4) prepared by the $\mathrm{CN}$ coordination group and signed by around seventy organizations articulate a mix of clear demands for social infrastructure, investment and public resources while also blaming neoliberal urbanism, the consequences of privatization and the lack of response to the crises affecting communities. At the same time, these documents reflect the $\mathrm{CN}^{\prime}$ 's declaration of their commitment to the community, their refusal to exist solely to solve public deficiencies and demand public responsibility as well as their prefigurative demands aimed to radically move towards a social and economic model that prioritises life.

As one $\mathrm{CN}$ participant reflects, this positioning focuses not only on what is done but also how it is achieved:

"I am convinced that care networks-the networks of neighbourhood solidarity-not only cover a lot of needs, but also favour two things: first, we are more conscious of what is going on with people that live nearby. In other words, situations of social exclusion and need are made visible. And secondly, in addition to demanding more information and a healthier provision of public services for provision, we can respond [to these] neighbours. Not in a distanced way, not as charity, but as a collective human act of solidarity." (Red de Cuidados de Chamberi; Video №1 ¿Who we are and what we do?)

\subsection{How did care networks start?}

The origin of CNs in Madrid, like in most Spanish towns and cities, are diverse. We will look at two key points of origin: mobilizations and the impact of NM in building an active and committed citizenry articulated through participatory programs and the 'City of Care' strategy. We will primarily base our conclusions on the evidence uncovered in our research, which is still in its initial stages.

On one hand, CNs are the outcome of the widespread mobilizations linked to the 15-M movement, in which many different people and social movements participated in often spontaneous ways. When 15-M first emerged, longstanding neighbourhood movements (Castells, 1986) did not immediately participate. However, this quickly changed when the movement addressed some of their demands from a territorial level. During the NM government, the president of the Federation of Neighbourhood Associations (FRAVM) became the councillor of Territorial Decentralization and introduced a participatory agenda including participatory budgeting implemented via local forums (or, Foros Locales) in city districts.

The 2009 financial crisis was not as powerful and deeply felt as that produced by the COVID19 pandemic. Its suddenness and depth reactivated care networks and resituated always present issues back on the frontline. As one young member of a network described: 
"We are a mutual support and solidarity network. We did not appear out of nowhere. This group is closely linked to social fabric that already existed in neighbourhoods. We have been supporting one another and collaborating". (Red de Ayuda Mutua Retiro; Video $n$-1 Who we are and what we do?)

During the 2009 financial crisis, networks mushroomed in vulnerable neighbourhoods where unemployment steadily increased for months to come. With the economy's gradual recovery, a lot of those networks gradually decreased their activity. In Spring 2020, the reactivation of networks was extremely quick due to the local political activist culture still in place (Janoschka \& Mota, 2020), in which many of the participants involved in the historical neighbourhood associations dating from the late 60s (Castells, 1983; Pérez \& Sanchez, 2008) continue to be active, as it is the case of the Regional Federation of Neighbourhood Associations (FRAVM), an active progressive force in the governance context of neoliberal urbanism.

\subsection{The NM local governance reforms}

The path opened by the NM local government in Madrid is key to explaining the activation of Care networks. Previously activated by organized citizens, NM raised expectations among non-previously mobilized ones through different policy strategies and instruments. Firstly, the 'City of Care' program was designed to be and launched as a transversal approach to different policy areas, including health, education, culture, and environment. Secondly, City Hall emphasized decentralising public action (in the form of policy, programs, and resources) by locating them in districts and neighbourhoods. This shift was implemented through transversal pilot programs that were tested as social innovation tools and prototyped in different places. One of the main policy lines of the NM local government of Mayor Manuela Carmena was to develop different programs in different neighbourhoods within different policy areas but with a transversal focus in fostering social cohesion either through interventions in public space, training and micro business environments, training disadvantaged social groups in community programs fostering public-social cooperation, etc. Some examples: Mares (Resilient urban ecosystems for a sustainable economy (IS2); Experimenta Distrito (citizens collective intelligence urban labs (IS3) or Imagina Madrid (a collaborative community innovation by neighbours and artists (IS4). The impact of these top-down programs is yet to be assessed.

The NM government made strong efforts to decentralise decision-making (Janoschka \& Mota, 2020) and to enhance participation in district forums (Foros Locales) that could make decisions regarding parts of the city budgets to be spent in their districts. These forums were organized around specific thematic working groups made up by volunteer explicitly committed citizens (Ayuntamiento de Madrid, 2021). Working groups' demands were passed by the District Council and sent to the different areas where they would be implemented. A garantist bureaucracy made administrative procedures long and complicated with an already austere budget that limited contracting and investment. A grassroot leader identifies these factors, as well as a disruptive contentious move towards demobilization (at least in one of the most active districts) after a period of enthusiastic engagement (Interview-AC-2020). These mechanisms have been in place since early 2016 and ended in 2019 when the newly elected neoliberal local government initiated its attempts to cancel these programs soon after taking office.

\subsection{From 'soft care' to 'hard care' provision}

In some districts, this participatory mechanism in which community activists and everyday citizens participated, was a key variable that explains the rapid mobilization and reactivation of CNs within days after the COVID-19 confinement started. The early CN's initial aim was to support neighbours and households, particularly older ones or families with children, that mainly required assistance running errands and meeting domestic needs or the provision of company. Soon there was an increasing demand from individuals who had lost their jobs or 
had hours cut and salaries diminished. Families in different neighbourhoods started to rely on the weekly distribution of basic food provisions that could meet the needs of thousands involving hundreds of volunteers in about 71 care networks (CM5).

"I think that one of the biggest challenges has been a shift in needs. At the beginning, we thought we would do people's shopping and run their errands when they were confined by COVID-19. But now, it is completely different. People are hungry, they literally don't have anything to eat. And there are more and more of them over time." (Red de Cuidados de Leganés; Video no1 ¿Who we are and what we do?)

Between March and the beginning of summer in May and June, the first wave of 'soft' care evolved into 'hard' care. Basic goods were supplied when they became scarce and expensive. Volunteers started to fabricate hydrogel, masks, screens, and PPE for health personnel, all to be distributed in health centres, hospitals and neighbours. They also made support calls, provided counselling services and legal advice, and provided care for children and teens facing hardships or lacking the technological devices needed to follow and participate in online schooling. Even today, large amounts of food continue to be distributed to thousands of families in Madrid (January 2021), thus 'filling the gap' left open by institutions.

Within a few weeks, the increasing demand for urgent help and the collapse of the social services in Madrid translated into what CNs defined as a "food emergency" that required providing food to peaks of 50.000 (CM6) people across the city between the first and second waves of the virus in September 2020. CNs also started to distribute clothes and other needed products. In summer, community needs and thus the number of volunteers gradually fell. However, in the fall, demands again rose as the second wave and the expanding economic crisis grew more dire. Although the figures are hard to estimate, by October of 2020, some of the most vulnerable and populated districts of Madrid faced emergency-level situations.

\subsection{Knitting the social fabric of Care networks}

Care networks in Madrid are horizontal, non-hierarchical and from the beginning are created through non-formalized structures. Most of them are not officially registered in administrative records. These characteristics are part of the consensual decision-making processes shared among the networks from the start of the pandemic. Networks agreed to communicate and coordinate, often virtually, and refused to become formalied organizations in order to maintain their autonomy, an ability to self-organize and a flexibility capable of seeking a commitment to act. They exchange information, debate resources and strategies that will make their services visible and put pressure on the local government. Despite the political commitment of most $\mathrm{CN}$ members, most networks side-lined political debates when first activated in order to focus on the provision of care. However, political debate gradually became more present in the networks that faced the growing re-neoliberalization of urban politics in the post-NM city. Most CNs and coordination groups embrace a very basic, but highly efficient, use of technology that includes the use of applications like WhatsApp or virtual drives for internal communications and the widespread use of free video conference software. This makes coordination among and between district networks a simple, yet work intensive task.

Despite this, over time, network debates have centred on this issue of formalization since food contributions are often received from large formal organizations such as Red Cross or Food Banks that require donation recipients to be formally registered. With locally based Christian organizations political relationships have relied on the personal and political relations present at the district level. Two strategies have been used to address this issue: CNs independently gathering resources through other informal support networks (like gathering individuals' donations in supermarkets) and using formalized organizations, mainly neighbour associations, to receive donations. 
"After two months, we have been slowly weaving a solidarity network with the neighbourhood: individual neighbours, businesses, grassroots initiatives, etc. They collaborate in different ways, from donations, to logistics. It is clear that we all share a common goal, and we do whatever we can to achieve that. But it's not only this; slowly relationships are created among people." (Despensa Solidaria de Vicalvaro; Video no 6 How do we organise?)

Often, $\mathrm{CNs}^{\prime}$ members also participate in neighbourhood associations, which has facilitated widespread collaboration at neighbourhood and city levels. This highlights the FRAVM's leadership role (CM8) and its ability to enhance the visibility of associations. From the beginning, FRAVM (Federación Regional de Asociaciones de Vecinos) has participated in the CN movement by providing technical and formal support, spaces to store food and assisting with other logistical concerns. They made the $\mathrm{CN}$ visible through their website, which includes a NC guide and a list of grassroot resources organized by district and neighbourhood. Relationships with big charity organiations have not been so fluid, and locally, it has depended on the personal and political relationships present in each district.

CNs' structures and dimensions vary across the 21 districts. Some districts have one CN while others have several. This generally depends on the population size and inhabitants' income levels. In big peripheral districts with large numbers of vulnerable households, CNs are organized by neighbourhoods and a coordination body that liaisons with other districts. It is common that information, goods, services etc., as well as information and know-how in collaborative knowledge making processes, are exchanged between the $\mathrm{CNs}$ located in different parts of the city. As autonomous groups, CNs have independently designed and participated in citylevel campaigns to increase their visibility and thus raise funds and food donations. One of the most successful of these was Kiwi Fest (CM7), an online music and cultural festival that brought together dozens of artists during a two-days event.

\subsection{Care networks and local administration}

CNs' and grassroots' in general relationships with local authorities somehow have followed a traditional path of dependence that only was interrupted between 2015 and 2019 during NM governance. In the twenty years prior to this, a right-wing party governed the city. Since the late 1990s, it has embraced a neoliberal management approach. Historically, the relationships between neighbourhood associations and the local government have not been very fluid, given that the former are linked directly or indirectly to left-wing parties. New urban activists after 15-M faced a different fate since they initially were not aligned with political parties (and furthermore, were rather sceptical about their role). Participants' youth and the movement's emphasis on transforming the city through social innovation situates these social actors, especially from the point of view of the neoliberal local government, as being part of a creative class rather than being political actors. Neoliberal urbanism often developed branding strategies which had been projecting an image of Madrid as a creative city to attract capital and talent (Sequera Fernández, 2013).

Currently, CNs are somehow identified with the political left and understood to be the heritage of the previous municipalist approach to the city. CNs and the FRAVM were very eager to diagnose, identify and communicate with the city administration about the increasing needs of thousands of families which had fallen off the radar of collapsed social services. Networks debated if they should "cover" or simply make visible social services' inability to provide basic relief to citizens and, thus, the administration's deficits. As an activist from a Despensa Solidaria states:

"We are witnessing how the public administration lacks both workers and economic resources, since most social services are privatized. And there are families that wait a 
month and a half for assistance. They have been relying on the Despensa Solidaria all this time, because they have absolutely no income at all." (Somos Tribu Quintana, Ciudad Lineal District; Video $n$ o4: What is missing on the part of public administrations?)

In the context of the pandemic, there has been little coordination or dialogue between CNs and the administration. There was also very little to no material support. Often in the most deprived districts, public social services referred families in need to CNs, where they can receive more accessible assistance without having to wade through complex bureaucratic procedures that many public officers could not respond to due to the collapse caused by existent demand.

CNs decided to make visible those problems, which in the context of lockdown orders and confinement, largely remained imperceptible to public opinion. Large lines of people collecting food at the Asociaciones de Vecinos in vulnerable neighbourhoods appeared in the media as political turmoil between the central, the regional and local governments grew. However, this coverage seldom deepened their performative discourse (Ruskal Melina, 2014). Still, despite CNs communication efforts, in which they organized online festivals, published manifestos, and circulated press releases the mainstream press rarely made $\mathrm{CNs}^{\prime}$ political facet visible. Instead, they were depicted as neighbours helping neighbours. In part, this was due to CNs' 'liquid' and informal character, which made them hard to understand and categorise. News about food relief tended to focus on a single protagonist, like large charity organizations such as the Catholic Church, Food Banks or the Red Cross (P4).

Therefore, it can be said that $\mathrm{CNs}$ have not been able to create meaningful connections or lines of dialogue with the public social service network mainly in part due to its rejection of the neoliberal local administration, but also to maintain its autonomy and the community focus that is its raison d'être.

\section{Conclusions}

\subsection{Trying to politicise care}

The invisibility of care networks in the Spanish media is far from insignificant. On the contrary, it is rooted in a long history that has contributed to barring community-level efforts from the spotlight and to situating it as a non-essential actor in the provision of care. In the meantime, the arena of community-level action has been defined as a non-essential element in understanding care and its provision, without becoming a consolidated field of research (Solis, Bujan \& Paredes Chauca, 2018; Martinez-Bujan, 2019).

This is due, firstly, to the rise of neoliberal policies in the 80 's which led to an "assistancebased shift" (Gelb, 1989, 59) that sought residual public support from only at those who lacked kinship or who were not integrated into the wage society (Mansell, 2006). This turn led to a decrease in the legitimacy of the welfare state and conversely to the market's greater presence in the provision of care and the growth of third sector entities. NGOs and institutionalized associations served as key agents to compensate for the weakness of the public administration and to fill the gaps opened by the withdrawal of the state and the destruction of existing communities (Federici, 2013). All in all, this trend contributed to the community's invisibility, which progressively was assimilated by the institutionalized volunteer sector. Spain is a specific example of a country, in which the 'community' lost its strength at the same time that the public welfare system was implemented (Carbonell, Galvez \& Rodriguez, 2014), thus marketing care around domestic service.

The refusal to recognize the community as a central actor in caring processes can also be explained by the difficulty of statically defining a heterogeneous field that, at the time, was highly dynamic. Some authors have only recently insisted on the role of the third sector in providing care for people who face social risks. But these studies continue to "obscure the 
diversity of experiences with this term 'community'" (Martinez Bujan, 2019, 8). Some assimilate the community sphere with the voluntary work managed by clearly official institutional associations and NGOs (Lyon \& Glusksmann, 2008). These approaches can exist in an organized way (e.g., churches, NGOs, neighbourhood associations) whose approaches vary between 'third sector', 'voluntary sector' (Daly \& Lewis, 2000) and others from the 'non-profit sector' (Razavi, 2007). Regarding the care networks being analysed, their very liquid nature, eminently horizontal structure, and categorical refusal to define themselves as an association are characteristics that accentuate their originality and make them strong. At the same time, this strength can also be a weakness in that the absence of political representation makes CNs somewhat difficult to be publicly understood and monitored by the conventional media.

In any case, the context of the 2008 economic crisis and the current COVID-19 pandemic contributed to shedding light on the virtue of communities as entities capable of giving and receiving care. In broad terms, CNs have participated in making visible a kind of vulnerability that, although already existent, had been publicly denied. The theoretical debates between the ethics of care and the ethics of justice include this question of political anthropology. The ethics of care is based on the vulnerability from which we must always start, and which makes us interdependent. On the contrary, the ethics of justice makes vulnerability, if not a shame, then at least an unthought-out one, to which they oppose an autonomous independent subject (Brugère, 2017). The virus, at least initially, has made us all potentially vulnerable, "always ever vulnerable" (Lussault, 2016). Thus, CNs precisely provide a political definition of care by enlightening these ordinary activities, by making neighbours more aware of their reciprocal needs and by supporting the most vulnerable households. The politicization of care has precisely pushed these tasks out from the domestic sphere in order to manage it in a common way. We believe that this conclusion is an element of the response to the debates that are stirring the field of care studies today and which sometimes tend to still locate them in the private domain.

Finally, this joint management of care activities informs the Spanish welfare state model. This community's preponderance may prove to be a means of compensating for the state's shortcomings in providing care and, more broadly, a mode of inventing sustainable social protection systems capable of meeting people's needs through the elaboration of collaborative public-social formulas that encourage tools for participation and the activation of solidarity-based care practices between citizens. Care by the commons does not replace the welfare state at all, and it should not. However, by strengthening the bonds of solidarity within a community, care exercised in and from the commons helps to forge relational autonomy, which contributes to vulnerable citizens' quality of life from a material, emotional and social point of view. After all, are calls not being made to transition from a welfare state that provides, to a 'city of care' where individuals are recognized as protagonists and beneficiaries of care exerted by all and in common?

\subsection{Origins and fate of the care networks}

So far, we have evaluated the origins of $\mathrm{CNs}$ as both a product of social movements and as a partial outcome of NM public policies implemented in following a path dependent on the context of neoliberal urbanism (Janoschka \& Mota, 2020). Thus, the return to a neoliberal local administration, this time in coalition with the ultra-right wing, implies a return, rather than a step back from a previous model that seeks to systematically dismantle many NM traits related to alternative models of governance that emphasise a community stronger role (P5). In contrast, several other policies emblematic during NM governance and, thus, severely attacked by right wing parties during the electoral campaign-such as low-emission zones (P6) and bike lanes-have not only not been redressed, but also incorporated into neoliberal urbanism's narrative regarding policy achievements. 
As we have demonstrated, CNs are socially innovative groups that have an origin in Spain's associative tradition and the 15-M anti-austerity movement. Like other NAUs, they are partly an outcome of NM's development of participative policies, mainly Local Forums, and in a lesser way a product of the 'City of Care' strategy that emerged after the destruction of innovative policy initiatives like public-social partnerships. Their politicization is evidenced in the evolution from calls for 'right to the city' to a 'right to life' in the neo-liberal city, made all the more apparent given the urgency of the crisis to which they responded. Still, the solidarity practices of CNs can effectively challenge and subvert the existing 'natural order of domination' (Arampatzi, 2017) imposed first by austerity and later by the return of neoliberal urbanism surrounding the 'post-political' condition that triggers collective discourses and emancipatory political practices about local welfare, neighbourhood governance and the opportunity of a 'fourth way' that relies on social movements to root social care in the commons.

Another question raised by CNs concerns the search for an equitable relationship between the public and the commons. Recently, the idea of co-responsibility too often has been used to justify the inhibition of public institutions in a context of declining rights and services" (Vega et al., 2018, 36). Thus, the idea is to find an arrangement that does not detract from state investment or delegate to community organizations the entirety of its management. The recognition of the community's capacity to be an actor in the provision of care must not be accompanied by the disempowerment of political powers or the embrace of a mercantile logic of 'uberization' (Zubero, 2017).

\subsection{Towards day-to-day community-led care: strengths and weaknesses of a DIY model of care in the commons}

Finally, the COVID-19 crisis is a key moment from which to examine the welfare state since it has called attention to the strengths and weaknesses of its structure. Care networks provide support to households when the capacity of assistance of the public sector is overwhelmed since the level of welfare provision and benefits aimed at long term support is not enough.

The pandemic reveals the power of self-management and the virtue of a do-it-yourself (DIY) ethos in order to palliate the state's withdrawal or its inability to treat citizen's day-to-day needs. Second, the strength of these self-help networks is based precisely on the bonds of solidarity deployed daily in order to satisfy individual's basic needs such as eating, sleeping and filling out an administrative form. In Madrid, the strength of CNs has also lied in their responsiveness, overwhelmingly more effective when compared to that of public services, as evidenced by their ability to address the urgency of a social demand that quickly transformed into the dramatic image of 'hunger lines'. The flexibility of their organization, activist militant character and embrace of new technologies also locates them within the realm of what we have called NAUs. All in all, these networks question the functioning of the welfare state and the provision of assistance beyond the long-term help traditionally given to dependent or sick people. Thus, care networks appear to be the invention of day-to-day micro-level care capable of responding to a rapid, dramatic increase of ordinary 'soft' and 'hard care' necessities.

To what extent do CNs question the welfare model in Spain in periods of crises? One of the problematic elements concerning care is the relegation of these tasks to the private sphere, at least in a range of states, as is the case with the Spanish family-centred model. Through these networks we can observe the removal of care tasks from the private sphere and their politicization as a result of their joint management. However, this fact can have serious consequences for the agents who provide this care. Furthermore, increased need for care accompanied by the withdrawal of the state runs the risk of giving families too much responsibility generating more social inequalities between households that can articulate a response to demands on the market and those that cannot. By extension, there is a risk or returning burden of care tasks to women, but this time at the community level, an issue reinforced by feminist 
studies carried out on the British community care system in the 1990s (Finch, 1993; Graham, 1997). A more detailed study of these care networks and their functioning could help measure whether this critique is still valid today.

Finally, aiming to embrace a shared - or "common" - management of public goods and services also raises the question of how to sustain and make these movements sustainable. According to some authors, community movements could embody 'the public in motion' (Fernandez-Savater, 2011). Nevertheless, a crucial question concerns the sustainability of these networks over time. This question is all the more urgent as CNs members, acting as volunteers, increasingly challenge the weight they bear as a result of the state's absence. Will the withdrawal of the public sector put an end to this 'public in motion'?

\section{References}

Arampatzi, A. (2017). The Spatiality of counter austerity politics in Athens, Greece. Emergent 'urban solidarity spaces'. Urban Studies, 54 (9): 2155-2171.

Ayuntamiento de Madrid (2017). Foros locales Retrieved from: https://foroslocales.madrid.es/. Accessed 20 January 2021.

Ayuntamiento de Madrid (2017). Presentación del Plan Madrid Ciudad de los cuidados, Retrieved from: http://madridsalud.es/que_es_mcc/. Accessed 20 January 2021.

Ayuntamiento de Madrid (2018). Ordenanza de Cooperación publico-social, Retrieved from: https://sede.madrid.es/portal/site/tramites/menuitem.5dd4485239c96e10f7a72106a8a409 a0/?vgnextoid=eb53ebd8dfcf3610VgnVCM2000001f4a900aRCRD\&vgnextchannel=6b3d8142 31ede410VgnVCM1000000b205a0aRCRD\&vgnextfmt=default. Accessed 21 January 2021.

Blanco, I., Cruz Gallach, H., Martínez Moreno, R. \& Parés, M. (2016). El papel de la innovación social frente a la crisis. Ciudad Y Territorio Estudios Territoriales (CYTET), 48(188), 249-260.

Blanco, I. \& León, M. (2017). Social Innovation, Reciprocity and contentious politics: Facing the socio urban crises in Ciutat Meridiana, Barcelona. Urban Studies, 54 (9) 2172-2188.

Blanco, I., Subirats, J. \& Gomá, R. (2018). El nuevo municipalismo: Derecho a la ciudad y comunes urbanos. Gestión y Análisis de Políticas Públicas; Issue 20.

Borderías, C., Torns, T. \& Bengoa, C. C. (2018). El trabajo de cuidados: historia, teoría y políticas. Madrid: Los Libros de la Catarata.

Brugère, F. (2017). L'éthique du «care». Paris: Presses Universitaires de France.

Castells, M. (2019). Prólogo. La política de la vida cotidiana. In L. Roth, A. Monterde, \& A. Calleja (Eds.), Ciudades Democráticas. La revuelta municipalista en el ciclo Post 15-M (9-12).

Castells, M. (1983). The city and the grassroots. Berkeley: University of California Press.

Ciudades del Cambio (2018). Geografía política del cambio municipalista, Atlas del Cambio. Colaboración público social. Retrieved from: http://ciudadesdelcambio.org/politica-publica/colaboracion-publico-social. Accessed October 2020. 
Chambon, J.L., David, A. \& Devevey, J.M. (1982). Les innovations sociales. Paris: Presses Universitaires de France.

Comas d'Argemir, D. (2016). Cuidados, género y ciudad en la gestión de la vida cotidiana. El espacio público en la ciudad neoliberal. Ciudadanías vulneradas y conflictos urbanos. México: Instituto de Investigaciones Sociales, UNAM.

Daly, M. \& Lewis, J. (2000). The concept of social care and the analysis of contemporary welfare states. The British journal of sociology, 51(2), 281-298.

Dardot, P. \& Laval, C. (2014). Commun: essai sur la révolution au XXle siècle. Paris: La Découverte.

Deusdad, B. A., Comas-d'Argemir, D., \& Dziegielewski, S. F. (2016). Restructuring long-term care in Spain: The impact of the economic crisis on social policies and social work practice. Journal of Social Service Research, 42(2), 246-262.

Ehrenreich, B., Hochschild, A. R. \& Kay, S. (Eds) (2003). Global woman: Nannies, maids, and sex workers in the new economy. London: Macmillan.

Esping-Andersen, G. (1990). The three worlds of welfare capitalism. Princeton: Princeton University Press.

Federici, S. (2013). Revolución en punto cero: Trabajo doméstico, reproducción y luchas feministas. Madrid: Traficantes de Sueños.

Fernández-Savater, A. (2011). "Lo público en movimiento», público.es; disponible Retrieved from: https://blogs.publico.es/fueradelugar/1113/lo-publico-en-movimiento.

Finch, J. (1993). The concept of caring: Feminist and other perspectives. Informal care in Europe, 5-22.

Fischer, B. \& Tronto, J. (1991). «Towards a Feminist Theory of Care». In E. Abel \& M. Nelson (Eds.), Circles of Care: Work and Identity in Women's Lives (35-62). Albany, New York: State University of New York Press.

Fumagalli, A. \& Lucarelli, S. (2015). Finance, austerity and commonfare. Theory, Culture \& Society, 32(7-8), 51-65.

García, B. (2017). New citizenship in Spain: From social cooperation to self-government. Citizenship Studies 21(4), 455-467.

Garrau, M. \& Le Goff, A. (2010). Care, justice et dépendance - Introduction aux théories du care. Paris: Presses Universitaires de France.

Gelb, A. H. (1988). Oil windfalls: Blessing or curse? Oxford: Oxford university press.

Gilligan, C. (1977). In a different voice: Women's conceptions of self and of morality. Harvard educational review, 47(4), 481-517. 
Gilligan, C. (1982). In A Different Voice, Cambridge: Harvard University Press.

Gobierno de España (2021) Medidas urgentes en el ámbito social y económico para hacer frente al COVID 19. Retrieved from: https://www.mscbs.gob.es/ssi/covid19/guia.htm Accessed 10 February 2021.

Gonzalez, S., Moulaert, F., Martinelli, F. et al. (2010). ALMOIN: How to analyse social innovation at the local level? In F. Moulaert, F. Martinelli, E. Swyngedouw, et al. (Eds.), Can Neighbourhoods Save the City? Community Development and Social Innovation (49-67). London: Routledge.

Graham, H. (1997). Feminist perspectives on caring. In J. Bornat, J. Johnson, C. Pereira, D. Pilgrim \& F. Williams (Eds.), Community care: A reader (124-133). London: Macmillan Education UK.

Hamel, P. (2014). Urban social movements. In H. A. van der Heijden (Ed.), Handbook of political citizenship and social movements (464-492). Cheltenham: Edward Elgar.

Harris, O. \& Young, K. (1981). Engendered structures: some problems in the analysis of reproduction. In J.S. Kahn, J.R. Llobera (Eds.), The Anthropology of pre-capitalist societies (109-147). Basingstoke: Palgrave.

Held, V., Kittay, E. F. \& Meyers, D. T. (1987). Feminism and moral theory. New Jersey: Rowman and Littlefield.

Herrera-Pineda, I. \& Ibanez-Gijon, J. (2016). Intercambio y sociabilidad en las redes de ayuda mutua del barrio madrileño de La Ventilla. Revista Española de Investigaciones Sociológicas, 154: 21-44.

Hochschild, A. R. (1995). The culture of politics: Traditional, postmodern, cold-modern, and warm-modern ideals of care. Social Politics: International Studies in Gender, State \& Society, 2(3), 331-346.

Janoschka, M. \& Mota, F. (2020). New municipalism in action or urban neoliberalisation reloaded? An analysis of governance change, stability and path dependence in Madrid (20152019), Urban Studies, First Published 17 Jun 2020. Retrieved from: https://journals.sagepub.com/action/doSearch?target=default\&ContribAuthorStored=Mota\%2C+Fabiola.

Kohlberg L. (1981). Essays on Moral Development. Vol. 1, The Philosophy of Moral Development. New York: Harper and Row.

Laugier, S. (2010). L'éthique du care en trois subversions. Multitudes, (3), 112-125.

Laugier, S. \& Paperman, P. (2005). Le souci des autres-éthique et politique du care. Paris: Éditions de l'EHESS.

Laugier, S. (Ed.) (2012). Tous vulnérables ? Le care, les animaux et l'environnement. Paris: Payot. 
Lussault, M. (2014). Nous sommes toujours-déjà vulnérables. Tous urbains, (4), 48-51.

Mansell, J. (2006). Deinstitutionalisation and community living: progress, problems and priorities. Journal of Intellectual and Developmental Disability, 31(2), 65-76.

Martínez Buján, R. (2019). Cuidados con "sentido común": desafíos, vacíos y contradicciones. Investigaciones Regionales, (44), 111-124.

Medina-García, C., de la Fuente, R. \& Van den Broeck, P. (2021). Exploring the Emergence of Innovative Multi-Actor Collaborations toward a Progressive Urban Regime in Madrid (20152019). Sustainability, 13(1), 415.

Meil, G., Romero- Balsas, P. \& Rogero-García, J. (2018). Parental Leave in Spain: Use, Motivation and Implications. Revista Española de Sociología, 27(3).

Méndez, R. (2017). Crisis, desposesión y mercado de trabajo en España: impactos en la Región Metropolitana de Madrid. Cadernos Metrópole, 19(38), 17-44.

Monterde, A. (2019). De la emergencia municipalista a la ciudad democrática. In L. Roth, A. Monterde, \& A. Calleja (Eds.), Ciudades Democráticas. La revuelta municipalista en el ciclo Post 15-M (25-52). Barcelona: Icaria

Moreno, L. (2001). La" vía media" española del modelo de bienestar mediterráneo. Papers: revista de sociología, 67-82.

Moulaert, F., Swyngedouw, E., Martinelli, F., \& Gonzalez, S. (Eds.) (2010). Can Neighbourhoods Save the City?: Community development and social innovation. London: Routledge.

Noddings, N. (1984). Caring: A Feminine Approach to Ethics and Moral Education. Berkeley: University of California Press.

Pautassi, L. \& Zibecchi, C. (Eds.) (2013). Las fronteras del cuidado: agenda, derechos e infraestructura. Buenos Aires: Editorial Biblos.

Peck, J. (2012). Austerity urbanism: American cities under extreme economy. City, 16(6), 626655.

Perez Orozco, A. (2006). Amenaza tormenta: la crisis de los cuidados y la reorganización del sistema económico. Revista de economía crítica, 5, 7-37.

Perez Orozco, A. (2014). Subversión feminista de la economía: aportes para un debate sobre el conflicto capital-vida. Madrid: Traficantes de sueños.

Plataforma Tercer Sector (2020). ¿Qué medidas está adoptando el Gobierno?. Retrieved from: http://www.plataformatercersector.es/es/tercer-sector-ante-crisis-covid-19/que-medidasesta-adoptando-el-gobierno. Accessed 05 February 2021.

Radio Televisión Española - RTVE (2021) Curva contagios y muertes por Coronavirus en España día a día. Retrieved from: https://www.rtve.es/noticias/20210326/curva-contagios-muertescoronavirus-espana-dia-dia/2010514.shtml\#: :text=El\%20nuevo\%20coronavirus \%20SARS\%2DCoV,590\%20fallecidos\%20desde\%20el\%20jueves. 
Raekstad, P. \& Gradin, S. (2020) Prefigurative politics: Building Tomorrow Today. London: Wiley.

Razavi, S. (2007). The political and social economy of care in a development context: Conceptual issues, research questions and policy options. Trabajo y empleo.

Rodriguez Enriquez, C. M. (2015). Economía feminista y economía del cuidado: Aportes conceptuales para el estudio de la desigualdad. Fundación Foro Nueva Sociedad; Nueva Sociedad, 256, 1-15.

Ruiz, V., Pozo, J., Gómez, M., Malmusi, D., Duarte, M. \& Sanz, E. (2018). Municipalismo y salud comunitaria: transformar desde los ayuntamientos. Informe SESPAS 2018. Gaceta Sanitaria, 32.

Russel, B. (2019). Beyond the Local Trap: New Municipalism and the Rise of the Fearless Cities, Antipode, 51, 989-1010

Sequera Fernández, J. (2013) Las políticas de gentrificación en la ciudad neoliberal: nuevas clases medias, producción cultural y gestión del espacio público : el caso de Lavapiés en el centro histórico de Madrid. Tesis doctoral. Retrieved from: https://eprints.ucm.es/ id/eprint/23816/.

Sorando, D. \& Leal, J. (2019). Distantes y desiguales: el declive de la mezcla social en Barcelona y Madrid. Revista Española de Investigaciones Sociológicas, 167: 125-148.

Tejerina, B., \& Perugorría, I. (Eds.) (2017). Crisis and social mobilization in contemporary Spain: The 15-M movement. London: Routledge.

Thompson, M. (2020). What's so new about New Municipalism? Progress in Human Geography, 1, 1-26.

Tronto, J. (1993). Moral Boundaries. A Political Argument for an Ethic of Care, New-York, London: Routledge.

Vega, C., Buján, R. M. \& Paredes, M. (2018). Introducción. Experiencias, ámbitos y vínculos cooperativos en el sostenimiento de la vida. In C.V. Solís, R.M. Buján, \& M.P. Chauca (Eds.), Cuidado, comunidad y común: experiencias cooperativas en el sostenimiento de la vida (1550). Madrid: Traficantes de Sueños.

Vercellone, C. (2015). From the crisis to the 'welfare of the common as a new mode of production. Theory, Culture \& Society, 32(7-8), 85-99.

Walliser, A. \& Uceda, P. (2020). La vivienda en España: Dinámicas de cambio en el modelo residencial. Informe España 2020. Madrid: Fundación Encuentros.

Walliser, A. \& De la Fuente (2018). Los nuevos activismos urbanos y la institucionalidad del cambio. In N. Barón-Yelles, \& J. Romero González (Eds.), Cultura territorial e innovación social. ¿Hacia un nuevo modelo metropolitano en Europa del Sur?. Valencia: Universitat de Valencia. 
Walliser, A. (2013). New Urban Activisms in Spain. Reclaiming public space in the face of crisis. Policy \& Politics, 43(3), 32-50.

Zubero, I. (2017). Sistemas de bienestar, políticas sociales y bienes comunes: tensiones y sinergias entre lo público y lo común. Documentación Social, 186, 115-134.

\section{Online Sources - Campaign material and media coverage}

Press:

P1: (2020, October 20). Colas del hambre, una pieza artística de 90.000 euros. Retrieved from El Pais https://elpais.com/espana/madrid/2020-11-12/colas-del-hambre-una-pieza-artisticade-90000-euros.html.

P2: (2020, October 20). Así ha evolucionado la deuda de Madrid desde que la disparó Gallardón hasta la intervención de Montoro. Retrieved from El Diario https://www.eldiario.es/madrid/hacienda-controlara-madrid-reducido-millones_1_3078604.html.

P3: (2020, October 20). Madrid y Barcelona lideran la rebelión municipal contra la austeridad. Retrieved from El Pais https://www.elperiodico.com/es/economia/20170417/madrid-barcelona-lideran-rebelion-municipal-contra-austeridad-ley-montoro-5961334.

P4: (2020, October 10). Las colas del hambre en el Madrid de Rockefeller. Retrieved from La Razón https://cutt.ly/ZkQ9v8W.

P5: (2020, October 15). El PP recupera Madrid y promete acabar con la herencia de Carmena. Retrieved from https://elpais.com/ccaa/2019/06/15/madrid/1560578298_100220.html.

P6: (2020, January 20) Madrid's new Right-wing government suspends low emissions zone. Retrieved from The Guardian: https://www.theguardian.com/world/2019/jun/18/madridnew-rightwing-council-suspends-low-emissions-zone.

\section{Campaign material:}

CM1: (2021, February 12). Madriz Kiwi Fest: primer festival online organizado por las redes de cuidados y solidarias de los barrios. Retrieved from https://www.europapress.es/cultura/musica-00129/noticia-madriz-kiwi-fest-primer-festival-online-organizado-redes-cuidados-solidarias-barrios-20200529135051.html.

CM2: (2020, October 20). Atlas del cambio - Geografía política del cambio municipalista. Retrieved from: http://ciudadesdelcambio.org/.

CM3: (2020, September 20). \#SeLavanLaCaraconNuestrasManos Comunicado Redes de Cuidados de Madrid. Retrieved from Madrid en Acción. Retrieved from: https://madridenaccion.org/comunicado-redes-de-cuidados-de-madrid-selavanlacaraconnuestrasmanos/.

CM4: (2020, September 20). Comunicado Redes Cuidados Madrid. Retrieved from: https://prosperesiste.nodo50.org/?p=2333. 
CM5: (2020, October 20). Redes de Solidaridad, Alimentos y Protocolo de Grupos de Apoyo (FRAVM). Retrieved from the blog Dinamiza tu Cuarentena https://dinamizatucuarentena. wordpress.com/2020/03/25/listado-de-las-redes-de-solidaridad-y-apoyo-de-los-distritos-ybarrios-de-madrid/.

CM6: (2020, October 20). Las redes vecinales distribuyen alimentos a más de 50.000 personas en toda la región. Retrieved from FRAVM: https://cutt.ly/tkQ3rqA.

CM7: (2020 October 10). Madrid Kiwi Fest Festival Facebook page. Retrieved from: https://www.facebook.com/madrizkiwifest/.

CM8: (2020, October 10). Redes de Solidaridad, Alimentos y Protocolo Grupos de Apoyo Retrieved from the Blog Dinamiza tu Cuarentena: https://dinamizatucuarentena.wordpress.com/2020/03/25/listado-de-las-redes-de-solidaridad-y-apoyo-de-los-distritos-y-barrios-de-madrid/.

\section{Institutional sources:}

IS1: (2020, October 20). Oficina del defensor del pueblo (Ombudsman): Reconocimiento del derecho a percibir atrasos por la demora en la aprobación de una prestación de dependencia. Retrieved from https://www.defensordelpueblo.es/resoluciones/reconocer-el-derecho-apercibir-atrasos-por-la-demora-en-aprobar-la-prestacion-para-cuidados-en-el-entorno-familiar-y-apoyo-a-cuidadores-no-profesionales-2/.

IS2: (2020, October 20). Proyecto MARES - Barrios, economía, futuro. Retrieved from https://maresmadrid.es/.

IS3: (2020, October 20). Proyecto Experimenta Districto. Retrieved from http://experimentadistrito.net/.

IS4: (2020, October 20). Proyecto Imagina Madrid. Retrieved from: https://www.imagina-madrid.es/es. 